\title{
Relevansi Pasal 29 Konstitusi Terhadap Sila Pertama Pancasila Sebagai Dasar Negara
}

\author{
Zainul Akmal \\ Zakmal08@gmail.com
}

\begin{abstract}
This study examined the relevance of norms in Article 29 of the 1945 Constitution of the Republic of Indonesia to the principle of Belief in the One and Only God in Pancasila as the state philosophy and an answer to faith crisis. The research aimed to identify the relevance of Article 29 of the 1945 Constitution of the Republic of Indonesia to the principle of Belief in the One and Only God in Pancasila and its feasibility as the highest constitution of the state to overcome the current social problem (crisis of faith). This was normative research with a philosophical approach and a descriptive qualitative analysis model. The study concluded that, first, Article 29 of the 1945 Constitution of the Republic of Indonesia is no longer relevant to the principle of Belief in the One and Only God in Pancasila. Secondly, Article 29 is no longer relevant to answer the issue of faith crisis because the norms do not regulate such matters.
\end{abstract}

Keywords: Faith; crisis of faith; state philosophy

\begin{abstract}
Abstrak
Penelitian ini mengkaji relevansi norma dalam Pasal 29 UUD NRI 1945 terhadap sila KeTuhanan Yang Maha Esa Pancasila sebagai dasar negara dan menjawab krisis keber-Tuhanan. Tujuan penelitian ini untuk mengetahui relevansi Pasal 29 UUD NRI 1945 terhadap Sila ke-Tuhanan Yang Maha Esa dalam Pancasila dan kelayakannya sebagai konstitusi tertinggi negara dalam mengatasi permasalahan sosial yang terjadi saat ini (krisis keber-Tuhanan). Jenis penelitian adalah normatif, dengan pendekatan filosofis dan model analisis deskriptif kualitatif. Penelitian ini menyimpulkan pertama, Pasal 29 UUD NRI Tahun 1945 tidak relevan lagi dengan Pancasila, sila ke-Tuhanan Yang Maha Esa. Kedua, Pasal 29 tidak relevan lagi dalam menjawab permasalahan krisis keber-Tuhanan karena normanya tidak mengatur hal demikian.
\end{abstract}

Kata-kata Kunci: Ke-Tuhanan; krisis keber-tuhanan; dasar negara 


\section{Pendahuluan}

Bangsa Indonesia menyatakan bahwa kemerdekaan adalah hak dari setiap manusia. Untuk mempertahankan kemerdekaannya, maka bangsa Indonesia melakukan pergerakan perlawanan terhadap penjajah yang merampas kemerdekaan bangsa ini. Dengan bermodalkan keinginan yang luhur dan semangat juang yang tinggi, bambu runcing menjadi senjata dalam melakukan perlawanan untuk menegakkan keadilan. Semangat dan keinginan luhur tidaklah berdiri sendiri melainkan bersandar kepada keyakinan terhadap Tuhan Yang Maha Esa.

Ke-Tuhanan dijadikan sebagai salah satu dasar negara, yang tertuang di dalam alinea keempat Pembukaan Undang-Undang Dasar Negara RI Tahun 1945 yang berbunyi:

"Kemudian dari pada itu untuk membentuk suatu Pemerintah Negara Indonesia yang melindungi segenap bangsa Indonesia dan seluruh tumpah darah Indonesia dan untuk memajukan kesejahteraan umum, mencerdaskan kehidupan bangsa, dan ikut melaksanakan ketertiban dunia yang berdasarkan kemerdekaan, perdamaian abadi dan keadilan sosial, maka disusunlah Kemerdekaan Kebangsaan Indonesia itu dalam suatu Undang-Undang Dasar Negara Indonesia yang terbentuk dalam suatu susunan Negara Republik Indonesia yang berkedaulatan rakyat yang berdasarkan kepada, KeTuhanan Yang Maha Esa, Kemanusiaan yang adil dan beradab, Persatuan Indonesia, Kerakyatan yang dipimpin oleh hikmat kebijaksanaan dalam permusyawaratan/perwakilan, serta dengan mewujudkan suatu keadilan sosial bagi seluruh Rakyat Indonesia"1.

Setelah dicantumkan poin Ke-Tuhanan Yang Maha Esa di dalam dasar filosofis bernegara yang tertuang di dalam Pembukaan Undang-Undang Dasar Negara RI Tahun 1945 kemudian dicantumkan pada Bab XI Agama, Pasal 29 ayat (1) "Negara berdasar atas Ke-Tuhanan Yang Maha Esa”.

Realitas sosial yang terjadi saat ini, banyak permasalahan yang bertentangan dengan dasar negara Republik Indonesia. Perbedaan agama, etnik dan pandangan politik adalah permasalahan yang marak. Ratu Hemas salah seorang Wakil Ketua DPD RI mengatakan:

"Saya sungguh prihatin ketika akhir-akhir ini bangsa kita jatuh kedalam berbagai konflik yang dipicu oleh perasaan ingin memenangkan kepentingan identitasnya. Baik agama, politik maupun etnik, yang menurut

\footnotetext{
${ }^{1}$ Ika Wikasari, Amandemen UUD 1945, Cetakan Pertama, Buku Pintar, Yogyakarta, 2013, hlm. 5.
} 
saya didasari oleh belum cukup mampu menghargai perbedaan. Bahkan untuk memaksakan kepentingan identitasnya, tak jarang menggunakan cara-cara kekerasan yang mengakibatkan jatuh korban" 2 .

Pernyataannya ini di sampaikan dalam sambutan buku "Asa Itu (masih) Ada" yang diterbitkan oleh Aliansi Nasional Bhineka Tunggal Ika (ANBTI). Kata sambutan ini menjelaskan realitas sosial yang tidak stabil. Negara sebenarnya sebagian belum mengaktualkan bahwa keamanan dan kenyamanan dapat diakses oleh setiap orang sehingga tidak ada yang perlu takut menunjukkan identitas kepercayaannya, agama ataupun politik.

Permasalahan lain yang tidak kalah penting seperti: kemiskinan cenderung mengalami kenaikan ${ }^{3}$, sehingga menyebabkan kematian sebanyak 2500 orang dan 411.500 orang sakit ${ }^{4}$ pada 2014/2015, kebakaran hutan dan menyebabkan kerugian mencapai Rp. 200.000.000.000.000,00 atau 10 persen dari APBN5, illegal fishing, narkoba, perdagangan orang, perbudakan dilaut, pembajakan kapal6, sumber daya alam yang dikelola asing7, perusakan lingkungan ${ }^{8}$ belum lagi kesejahteraan, kualitas dan kuantitas guru. ${ }^{9}$

Hal demikian juga terjadi di masa klasik, tapi dalam bentuk yang berbeda, misalnya: pertama, tindakan Soekarno membubarkan Konstituante dan mendekritkan kembali ke Undang-Undang Dasar 1945. Kedua, Soekarno membubarkan DPR dan menggantinya dengan DPR baru yang anggotanya ditunjuknya sendiri. Hal demikian ini menurut Hatta menunjukkan perbuatan

${ }^{2}$ Divisi kampanye ABTI, Asa Itu (Masib) Ada-orang Muda Dalam Antologi Esai Keberagaman, Cetakan Pertama, ANBTI, Jakarta Selatan, 2010, Hlm VII.

${ }^{3}$ http://www.bps.go.id/Brs/view/id/1158Kemiskinan diakses pada tanggal 10 Juli 2017.

4 http://m.merdeka.com/peristiwa/pakar-indonesia-masih-rawan-pangan.html diakses pada tanggal 26 Juni 2017.

5http://bisniskeuangan.kompas.com/read/2015/12/20/121300726/5.masalah.ekonomi.Indonesia.yang.t idak.boleh.terulang.di.tahun2016 diakses pada tanggal 26 Juni 2017.

http:/ /m.okezone.com/read/2015/09/16/320/1215049/rizal-ramli-ungkap-masalah-maritim-diindonesia diakses pada tanggal 25 Juni 2017.

$7 \mathrm{http}: / / \mathrm{m}$.liputan6.com/news/read/2371659/ini-akar-masalah-freport-versi-mantan-dirjen-minerbaesdm diakses pada tanggal 24 Juni 2017.

${ }^{8}$ Keputusan Menteri Lingkungan Hidup Nomor 14 Tahun 2016 tentang Reklamasi Dan Revitalisasi Pantai Utara 1420187847. diakses pada tanggal 24 Juni 2017 
yang bertentangan dengan Pancasila. ${ }^{10}$ Menurut peneliti ini adalah salah satu bentuk belum meresap sila ke-Tuhanan pada diri para anak bangsa.

Begitu komplitnya permasalahan negeri ini, dalam berbagai bidang. Perilaku sebagian anak bangsa ini seperti perilaku tidak ber-Tuhan. Tuhan seakan-akan "telah mati" pada diri mereka. Bagaimana mungkin seorang yang meyakini keberadaan Tuhan ada didekatnya namun ia melakukan perusakan alam? Bagaimana mungkin orang yang meyakini adanya Tuhan dalam hidupnya melakukan syi'ar kebencian, perampokan, pencurian, narkoba, perdagangan orang, perbudakan di laut, pembajakan kapal, membiarkan kemiskinan semakin menjamur, pendidikan yang mahal, belum lagi tentang kuantitas dan kualitas guru bermasalah, dan berprilaku para pejabat negara yang sewenang-wenang tanpa mengikuti aturan yang telah dibuat? Masih banyak pemasalahan lainnya.

Bila melihat pada dasar negara dan Undang-Undang Dasar sebagai bentuk nyata dari dasar negara, sudah ada pasal yang mengatur tentang ke-Tuhanan. Ironisnya pada pasal ini tidak dijelaskan bagaimana seseorang itu ber-Tuhan Yang Maha Esa atau lembaga apa yang memberikan pemahaman tentang Tuhan Yang Maha Esa dalam bernegara. Pasal 29 ayat (1) hanya penekanan kembali sila pertama selaku dasar yang paling mendasar sebagai filosofis bernegara ke dalam Pasal Undang-Undang Dasar Negara RI Tahun 1945.

Bila melihat pada Pasal 29 ayat (2) “Negara menjamin kemerdekaan tiap-tiap penduduk untuk memeluk agamanya masing-masing dan untuk beribadat menurut agamanya dan kepercayaan itu". Negara kembali berlepas tangan dengan membiarkan warga negaranya ber-Tuhan tanpa diberi terlebih dahulu bekal untuk mengenal Tuhan. Ayat (2) Pasal 29 ini negara membiarkan agama-agama dan aliran kepercayaan untuk menempa warga negaranya untuk ber-Tuhan. Bagaimana jadinya bila seseorang mengerjakan sesuatu tanpa dibekali terlebih dahulu pemahaman tentang sesuatu itu?

Negara hanya bermaksud untuk memberikan jaminan perlindungan kepada warganya untuk memilih keyakinan atau beragama, yang sudah tertuang di dalam Undang-Undang Dasar Negara RI Tahun 1945 (selanjutnya di tulis Undang-

${ }^{10}$ Muhammad Hatta, Menuju Negara Hukum, Cetakan Kedua, Idayu Press, Jakarta, 1977, hlm. 15 
Undang Dasar) Bab XA Hak Asasi Manusia, Pasal 28E ayat (1) bahwa "Setiap orang bebas memeluk agama dan beribadat menurut agamanya, memilih pendidikan dan pengajaran, memilih pekerjaan, memilih kewarganegaraan, memilih tempat tinggal di wilayah negara dan meninggalkannya dan berhak kembali". Dan ayat (2) bahwa "Setiap orang berhak atas kebebasan meyakini kepercayaan, menyatakan fikiran dan sikap sesuai dengan hati nuraninya". Peneliti merasa perlu untuk melakukan penelitian tentang "Relevansi Pasal 29 UUD NRI Tahun 1945 Terhadap Sila Ke-Tuhanan Yang Maha Esa Dalam Pancasila Sebagai Dasar Negara".

\section{Rumusan Masalah}

Berdasarkan latar belakang masalah diatas maka permasalahan yang akan dikaji adalah sebagai berikut Pertama, apakah Pasal 29 UUD NRI Tahun 1945 masih relevan dengan Pancasila (sila pertama Ke-Tuhanan Yang Maha Esa) dalam menjawab permasalahan krisis keber-Tuhanan? Kedua, apakah Pasal 29 UUD NRI Tahun 1945 masih relevan dalam menjawab permasalahan krisis keber-Tuhanan?

\section{Tujuan Penelitian}

Pertama, untuk meninjau ulang relevansi norma yang berada dalam Pasal 29 UUD NRI Tahun 1945 terhadap sila KeTuhanan Yang Maha Esa Pancasila sebagai dasar bernegara. Kedua, untuk mengetahui kelayakan dari Pasal 29 UUD NRI Tahun 1945 sebagai konstitusi tertinggi negara dalam mengatasi permasalahan sosial yang terjadi saat ini.

\section{Metode Penelitian}

Jenis penelitian ini adalah normatif, yakni mengkaji hukum dari perspektif internal struktur norma hukum dan menemukan serta mengajarkan suatu doktrin untuk menegakkan hukum. Pendekatan yang digunakan adalah filosofis, dengan menggunakan penalaran yang logik. Objek penelitian adalah Pasal 29 UndangUndang Dasar Negara Republik Indonesia Tahun 1945 dan Sila Ke-Tuhanan Yang Maha Esa dalam Pancasila untuk melihat relevansinya dalam menjawab permasalahan sosial yakni permasalahan krisis keber-Tuhanan. 


\section{Hasil Penelitian dan Pembahasan}

\section{Undang-Undang Dasar Sebagai Manifestasi Pancasila}

Pancasila adalah dasar filosofi negara Republik Indonesia yang tercantum di dalam Pembukaan Undang-Undang Dasar. Sebelum lebih jauh untuk melihat relevansi antara Undang-Undang Dasar dengan sila ke-Tuhanan Yang Maha Esa Pancasila, terlebih dahulu sebaiknya peneliti menjelaskan apa yang dimaksud relevansi pada penelitian ini. Peneliti merujuk pada "Kamus Besar Bahasa Indonesia-online", relevan diartikan "Kait-mengait, bersangkut-paut dan berguna secara langsung"11, sedangkan relevansi diartikan "hubungan dan kaitan". ${ }^{12}$

Peneliti akan melihat relevansi Undang-Undang Dasar dengan sila keTuhanan Yang Maha Esa Pancasila dalam konteks kekinian. Apakah UndangUndang Dasar dalam menjawab permasalahan krisis keber-Tuhan masih relevan dengan sila ke-Tuhanan Yang Maha Esa Pancasila? Agar duduk permasalahan lebih jelas, maka terlebih dahulu peneliti akan menjelaskan tafsir dari sila keTuhanan Yang Maha Esa Pancasila itu sendiri. Tujuannya tidak lain agar jelas ukuran relevan atau tidaknya.

Ke-Tuhanan Yang Maha Esa adalah sila pertama dalam Pancasila. Pertama kali yang menyatakan salah satu dasar negara Republik Indonesia ke-Tuhanan adalah M. Yamin, pada sidang pertama Panitia Persiapan Penyelidik Kemerdekaan Indonesia (PPPKI). Yamin memposisikan ke-Tuhanan pada poin ketiga dari lima dasar yang disampaikannya. M. Yamin mengatakan sebagai berikut:

“...Bangsa Indonesia yang akan bernegara merdeka itu, ialah bangsa yang beradaban luhur, dan peradabannya itu memiliki Tuhan Yang Maha Esa. Oleh sebab itu maka dengan sendiri kita insyaf, bahwa negara kesejahteraan Indonesia merdeka itu akan berke-Tuhanan. Tuhan akan melindungi negara Indonesia merdeka"13.

Muh. Yamin meyakini bahwa bangsa Indonesia adalah bangsa yang memiliki peradaban yang luhur. Bisa dipahami dari pernyataannya ini bahwa yang dimaksud peradaban yang luhur adalah peradaban yang memiliki Tuhan Yang Maha Esa. Sebagaimana pernyataan Yamin, bahwa "Sebagai bangsa yang

\footnotetext{
11 http://kbbi.web.id/relevan diakses pada tanggal 24 Juni 2017

12 http:/ / kbbi.web.id/relevansi diakses pada tanggal 24 Juni 2017

${ }^{13}$ Muh. Yamin, Naskah Persiapan Undang-Undang Dasar 1945, Cetakan Kedua, Jilid Pertama, 1971, hlm. 94.
} 
mempunyai peradaban luhur, maka peradaban bangsa Indonesia ialah adab yang ber-Tuhan Yang Esa"14.

Sukarno adalah orang kedua yang mengajukan dasar ke-Tuhanan sebagai dasar negara, dalam sidang awal pembentukan Indonesia merdeka setelah M. Yamin. Sukarno menyebutnya dengan istilah ke-Tuhanan yang berkebudayaan. Sukarno mengatakan:

"Prinsip Indonesia dengan bertaqwa kepada Tuhan Yang Maha Esa. Prinsip ke-Tuhanan! Bukan saja bangsa Indonesia ber-Tuhan, tetapi masing-masing orang Indonesia ber-Tuhannya sendiri. Yang Kristen menyembah Tuhan menurut petunjuk Isa Al Masih, yang belum ber-Tuhan menurut petunjuk Nabi Muhammad Saw, orang Budha menjalankan ibadatnya menurut kitabkitab yang ada padanya. Tapi marilah kita semua ber-Tuhan. Hendaknya negara Indonesia ialah negara yang tiap-tiap orangnya dapat menyembah Tuhannya dengan cara yang leluasa. Segenab rakyat ber-Tuhan secara kebudayaan, yakni dengan tiada egoisme agama. Dan hendaknya negara Indonesia satu negara yang ber-Tuhan"15.

Sukarno sangat tegas mengatakan, bahwa berbicara Pancasila dan salah satunya sila ke-Tuhanan sebagai dasar negara bukanlah hal yang cangkok dari kepercayaan bangsa lain, namun hal ini adalah hal yang asli pada bangsa Indonesia. Sukarno menjelaskan bagaimana orang terdahulu ber-Tuhan sebagai berikut:

"Tatkala ia (manusia) masih hidup di alam hutan, di dalam gua-gua, apa yang ia sembah? ...Ia sembah bulan dan bintang itu. ...Ia menyembah kepada petir. ...Di dalam Begawad Gita Krisna berkata kepada Arjuna, Kau kenal aku? Aku is ik. Aku adalah hidup, aku adalah angin. Aku tiada mula tiada akhir, aku adalah di dalam gloranya air samudra yang membanting di pantai. Itu juga disembah". ${ }^{16}$

Menurut Ahmad Syafii Maarif, tafsiran Muhammad Hatta terhadap Pancasila merupakan tafsiran yang bisa di terima oleh berbagai kelompok aliran politik. ${ }^{17}$ Hatta mengatakan, dasar ke-Tuhanan Yang Maha Esa menjadi pemimpin dari empat sila lainnya. Berikut pernyataan Hatta:

\footnotetext{
hlm. 462.

${ }^{14}$ Muhammad Yamin, Pembahasan Undang-Undang Dasar Republik Indonesia, Djakarta, Jajasan Prapantja, 1960,

${ }^{15}$ Muh. Yamin, Naskah Persiapan ..., Op. Cit., hlm. 77 dan 78.

16 Sukarno, Pancasila, Cetakan Pertama, Idayu Press, Jakarta, 1984, hlm. 41 dan 42.

17 Ahmad Syafi'i Ma'arif, Islam dan Masalah Kenegaraan, Cetakan Ketiga, LP3ES, Jakarta, 1996, hlm. 154.
} 
“Dasar ke-Tuhanan Yang Maha Esa jadi dasar yang memimpin cita-cita negara kita, yang memberikan jiwa kepada usaha penyelenggaraan segala yang benar, adil dan baik, sedangkan dasar kemanusiaan yang adil dan beradab adalah kelanjutan dalam perbuatan dan praktik hidup dari pada dasar yang memimpin tadi. Dalam susunan sekarang ini dasar kemanusiaan yang adil dan beradab harus menyusul, berangkaian dengan dasar yang pertama. Letaknya tidak dapat dipisahkan dari itu, sebab ia harus dipandang sebagai kelanjutan kedalam praktik hidup dari pada cita-cita dan amal ke-Tuhanan Yang Maha Esa"18. “...Dasar persatuan Indonesia menegaskan sifat negara Indonesia sebagai negara nasional, berdasarkan ideologi sendiri dengan bersendi kepada Bhineka Tunggal Ika, sedangkan dasar kerakyatan menciptakan pemerintahan yang adil, yang dilakukan dengan rasa tanggungjawab, agar terlaksana keadilan sosial, yang tercantum sebagai sila kelima. Dasar sila kelima ini adalah pedoman dan tujuan kedua-duanya"19. "...Di bawah bimbingan sila yang pertama, sila keTuhanan Yang Maha Esa, kelima sila itu ikat-mengikat"20.

Tafsir Pancasila yang tidak menjadi perdebatan antara golongan Islam dan kebangsaan adalah tafsiran Muhammad Hatta, menurut Ahmad Syafii Maarif. Peneliti menerima pendapat Muhammat Hatta, namun dengan interpretasi yang sedikit berbeda dan tentunya tidak lepas dari pandangan "Yang Esa". Sila pertama memang dasar dari empat sila lainnya. Sila Ke-Tuhanan Yang Maha Esa adalah yang paling dasar dan melingkupi dari lima sila tersebut. Nilai-nilai yang terkandung di dalam sila pertama seharusnya menjadi landasan nilai-nilai moral bernegara.

Pandangan "Yang Esa", artinya segala sesuatu tidaklah terpisah karena keEsaan Tuhan bukanlah dalam arti bilangan. Ke-Esaannya juga bukan dalam arti menyatu, karena bila diartikan menyatu ada selain dari diri-Nya yang Esa. Konsep dari penyatuan adalah adanya dua sesuatu dan kemudian dua sesuatu itu melebur menjadi satu. Seperti yang peneliti jelaskan pada bab sebelumnya, bahwa Dia bersama segala sesuatu bukan dalam arti menyatu dengan segala sesuatu dan kebersamaan-Nya juga bukan dalam arti terpisah dari segala sesuatu itu. Jika penjelasan Darji di atas hanya mengatakan bahwa Tuhan ini bisa dibuktikan dalam kaidah logika namun menurut peneliti bisa lebih dari itu, yakni juga menggunakan

18 Muhammad Hatta, Pengertian Pancasila, Idayu Press, Jakarta, 1977, hlm. 17.

${ }^{19}$ Ibid., hlm. 28.

${ }^{20}$ Ibid., hlm. 20. 
kaidah ilmiah. Inilah pandangan "Yang Esa" dan bisa dibuktikan dengan menggunakan metode filsafat Islam (Muhammad Bagir Shadr) yang berlandaskan alam (ilmiah) dan dengan rasio (pengetahuan) sebagai neraca.

Pandangan "Yang Esa" bukanlah dalam arti bilangan sehingga tidak ada selain diri-Nya, jika ada selain diri-Nya maka terjadilah dualitas antara "Dia" dan yang selain "Dia". Dualitas akan berimplikasi gugurnya pandangan "Yang Esa", karena ada selain diri-Nya. Peneliti lebih tertarik bila menyebut sila kedua, ketiga, keempat dan sila kelima dengan manifestasi-manifestasi Ilahi atau tanda-tanda dari Tuhan itu sendiri. Tanda dan penanda atau sifat dengan yang disifati bukanlah dua hal, namun hal tersebut ibarat jalan dan tujuan yang tidak terbayangkan terpisah. Dalam pandangan "Yang Esa" maka tidak ada selain diri-Nya. Maka peneliti sangat mempertanyakan apa yang dimaksud olah Darji dengan istilah esa sifat, zat dan perbuatan, apakah sama dengan yang peneliti jelaskan di atas atau bagaimana?

Sila selain sila pertama yang dimaksud dengan manifestasi Ilahi adalah ketika manusia menunjukkan sifat kemanusiaannya dan keadilannya sehingga manusia layak disebut sebagai makhluk beradab inilah manifestasi dari Ilahi. Ketika manusia tersebut bersatu untuk menegakkan kebenaran dan menjaga bangsanya dari segala macam bentuk kezaliman di dalam suatu negara inilah manifestasi Ilahi. Ketika manusia memecahkan suatu masalahnya dengan musyawarah yang hikmat, bijaksana baik secara langsung atau melalui perwakilan dan menaati hasil musyawarah tersebut inilah yang peneliti sebut dengan manifestasi Ilahi. Ketika semua itu terimplementasikan dan keadilan sosial tercapai inilah manifestasi dari Tuhan Yang Maha Esa, Yang Maha Pengasih, Maha Penyayang, Maha Adil, Maha Bijaksana, Maha Benar, Maha Pencipta, Maha Menepati Janji, Maha Mengetahui dan masih banyak sifat-sifat lainnya yang belum peneliti sebutkan.

Sila kedua hingga keempat merupakan gambaran dari sifat Tuhan. Ketika manusia berprilaku sebagai mana sifat Tuhan atau prilaku Tuhan, maka manusia tersebut telah menjadikan dirinya manifestasi dari Tuhan. Sebagaimana telah peneliti jelaskan pada bab sebelumnya, bahwa manusia memiliki fitrah (nilai-nilai kemanusiaan) yang sifatnya bawaan dalam bentuk potensi. Al Qur'an menyebut 
fitrah itu adalah gambaran dari fitrah diri-Nya yang Maha Pencipta. Manusia yang meyakini pandangan dunia yang sifatnya "Esa", maka akan berperilaku sebagaimana fitrahnya atau yang disebut dalam istilah ini Pancasila oleh para pendiri negara Republik Indonesia.

Interpretasi di atas membawa peneliti kepada suatu kesimpulan bahwa Pancasila itu Ekasila, namun bukan dalam arti Ekasila yang dimaksud oleh Sukarno yakni "Gotong royong". Bila melihat dari sebagian penjelasan di atas tentang sila ke-Tuhanan Yang Maha Esa memang menarik, namun bila dibawa pada penjelasan bab sebelumnya yang membahas tentang Ekasila atau gotong royong, peneliti memiliki sudut pandang yang berbeda. Pandangan Sukarno tentang gotong royong telah meniadakan ke-Esaan karena gotong royong yang dimaksud adalah kebersamaan dari banyak orang untuk mengerjakan suatu hal secara bersama. Ketika kebersamaan tercapai maka tidak ada lagi yang namanya individu. Pandangan ini tetap mengafirmasikan yang banyak, sedangkan pandangan "Yang Esa" menafikan yang banyak dan mengafirmasi "Yang Esa". Penjelasan gotong royong oleh Sukarno tidak adalagi penjelasan tentang Tuhan yang ada adalah masyarakat yang mengerjakan sesuatu secara bersama.

Pandangan Sukarno tentang Ekasila ini akan berimplikasi gugurnya pandangan "Yang Esa" karena mengafirmasi yang banyak. Ekasila yang dimaksud oleh Sukarno bisa diterima bila interpretasi gotong royong adalah bentuk dari manifestasi Ilahi yang mencerminkan ke-Esaan-Nya, artinya tetap mengafirmasi "Yang Esa" dan menafikan yang banyak. Ketika masyarakat melakukan sesuatu secara bersama-sama atau bergotong royong, maka hilanglah individu-individu yang banyak. Hilang atau menafikan yang dimaksud bukan dalam arti meniada melainkan menjadi tanda adanya "Yang Esa" yakni Tuhan Yang Maha Esa. Gotong royong yang dimaksud tidak boleh dalam maksud negatif, melainkan dalam menegakkan kebenaran atau dalam arti positif sehingga perbuatan tersebut mencerminkan sifat dari Tuhan.

Penjelasan Pancasila yakni sila Ke-Tuhanan yang begitu indah dan memukau apakah memiliki relevansi dengan Undang-Undang Dasar dalam kontek krisis keber-Tuhanan? Pancasila yakni sila ke-Tuhanan Yang Maha Esa adalah garis besar yang menjadi tolak ukur dalam membuat suatu aturan (Undang-Undang Dasar). 
Pancasila hanya sebagai sumber atau batasan yang bersifat umum. Sifat yang umum ini yang membuat Pancasila tidak akan habis dimakan zaman, artinya akan tetap berlaku sepanjang masa.

Sila ke-Tuhanan Yang Maha Esa bisa dikatakan relevan dengan UndangUndang Dasar dalam konteks ini, bila memuat Pasal yang mengatur bagaimana seseorang bisa mengatasi krisis keber-Tuhanannya. Manusia yang berke-Tuhanan adalah manusia yang memiliki peradaban luhur. Manusia yang memiliki peradaban luhur adalah manusia yang mempraktikkan dalam kehidupan sehariharinya sila ke dua, ke tiga dan ke empat, dengan demikian sila ke lima akan teraktual (menjadi nyata). Apakah Undang-Undang Dasar mengakomodir hal ini?

Undang-Undang Dasar Negara Republik Indonesia saat ini, memang ada pasal yang memuat tentang ke-Tuhanan Yang Maha Esa, yakni Pasal 29 yang berbunyi "Negara berdasar atas ke-Tuhanan Yang Maha Esa". Sesuatu yang perlu diingat dalam permasalahan ini yakni krisis keber-Tuhanan, artinya bukan negara yang tidak ber-Tuhan namun manusia yang berada dalam negaralah yang mengalami permasalahan. Jadi filosofis dasar negara tidaklah bermasalah dalam menjawab permasalahan ini, namun yang menjadi sorotan adalah aturan dasar yang di turunkan dari dasar negara.

Berbicara tentang hal praktis, artinya aturan dasar yang diturunkan dari dasar negara mestilah bisa menjawab permasalahan kekinian. Pancasila adalah sesuatu yang sifatnya tetap, sedangkan Undang-Undang Dasar yang akan selalu disesuaikan dengan Pancasila. Semakin tua (dewasa) negara ini maka akan semakin terlihat kekurangan dari aturan tersebut, disebabkan semakin menyempurnanya suatu negara itu. Undang-Undang Dasar seharusnya mengatur hal-hal yang sifatnya penting dan mendasar. Sesuatu itu bisa dipahami penting dan mendasar bisa dilihat dari kebutuhan dari zaman itu.

Memang Undang-Undang Dasar tidak akan mengatur secara detil tentang aturan dari suatu negara tetapi selayaknya Undang-Undang Dasar memuat hal-hal yang sifatnya mendasar. Pancasila yakni sila ke-Tuhanan sebagai Ruh dari Pancasila itu sendiri seharusnya dipahami dan diimplementasikan oleh rakyat Indonesia di dalam kehidupannya sehari-hari. Untuk memahami sila ke-Tuhanan 
maka sila kemanusiaan menjadi modal utama karena dalam sila kemanusiaan terkandung potensi untuk mencari kebenaran atau pengetahuan.

Setiap manusia memiliki kecenderungan untuk mengetahui sehingga di dalam Undang-Undang Dasar mengakui dan menjamin dengan istilah hak untuk mendapatkan pendidikan. Hak ini yang disebut juga dengan hak asasi manusia karena hak ini bukanlah perolehan melainkan pemberian dari sang Maha Pencipta. Negara dalam mengakomodir atau menjamin hak ini mengaturnya dalam bentuk jaminan untuk mendapatkan pendidikan, namun pendidikan yang dimaksud oleh negara tidak menyentuh substansi dari permasalahan ini. Negara menjadikan pendidikan agama sebagai alat untuk memperkenalkan tentang Tuhan kepada warga negaranya.

Sub-bab selanjutnya akan menjelaskan lebih rinci akibat dari pengenalan Tuhan yang diserahkan kepada pendidikan agama yang sifatnya doktrin. Tidak jarang pengetahuan yang diperoleh dari pendidikan agamanya, orang menjadi bersifat tertutup. Sebagian besar orang meyakini bahwa apa yang disebutkan oleh ulama agamanya itulah kebenaran, namun yang menjadi permasalahan bahwa pendidikan yang diperoleh melalui ulama agama terkadang bertentangan dengan prinsip dasar dari agama itu sendiri. Tidak jarang juga orang meninggalkan rasionalitasnya dan mengikuti apa kata ulamanya sedangkan rasio atau keberfikiran itu datangnya dari Tuhan. Apakah ada kemungkinan ada kontradiksi antara rasional (akal manusia) dengan wahyu Ilahi?

Ahmad Syafii Maarif, berdasarkan kutipannya tentang pernyataan Natsir pada suatu pidato yang mengatakan, "Pancasila ingin terus netral tanpa warna", memberikan penjelasan bahwa, "Karena itu penafsiran seseorang terhadap Pancasila bisa bermacam-macam, tergantung pada pandangan filosofis seseorang itu." 21 Menurut peneliti ini menariknya, yakni pandangan filisofis dari seseorang itu. Hal ini dianggap oleh golongan agama bahwa tafsiran Pancasila diselewengkan. Sesuatu yang menarik dalam Islam yang mengatakan bahwa awal agama adalah "Mengenal Allah". Mengenal Tuhan adalah hal yang subtansi dalam orang beragama. Sebelum memilih agama mana yang harus diikuti, seseorang

${ }^{21}$ Ahmad Syafii Maarif, Islam ..., Op. Cit., hlm. 144. 
seharusnya terlebih dahulu mengenal Tuhannya, sehingga orang tersebut bisa memilih agama mana yang harus diikutinya yang sesuai dengan Tuhan yang dikenalnya.

Pengenalan Tuhan yang demikianlah yang peneliti maksud dengan pengenalan filosofis yang tahan uji. Artinya pemahamannya tentang Tuhan bisa diperdebatkan dan tidak akan gugur diperdebatkan. Ketika Tuhan telah dikenal dan ada agama yang sesuai dengan pengenalan Tuhan yang dipahaminya, maka agama yang demikianlah yang peneliti maksud dengan agama harus menjadi ruh dalam bernegara.

Perlu kiranya dilakukan tinjauan antara relevansi Pasal 29 Undang-Undang Dasar dalam hal menjawab permasalahan krisis keber-Tuhanan. Apakah benar Pasal 29 tidak lagi relevan dalam menjawab permasalahan krisis keber-Tuhanan? untuk menjawab pertanyaan ini akan peneliti urai pada sub bab berikut ini.

\section{Undang-Undang Dasar dan Krisis Keber-Tuhanan}

Undang-Undang Dasar Negara Republik Indonesia Tahun 1945 telah mengatur tentang ke-Tuhanan. Pasal 29 ayat (1) "Negara berdasarkan atas KeTuhanan Yang Maha Esa"22. Dalam Pasal 29 ayat (1) ini, Undang-Undang Dasar telah memuat pengakuan bahwa negara Republik Indonesia memiliki keyakinian akan keberadaan Tuhan Yang Maha Esa. Pertanyaan selanjutnya, dengan negara yang berdasarkan atas ke-Tuhanan Yang Maha Esa, apakah menjadikan para penerus bangsanya berke-Tuhanan Yang Maha Esa?

Inilah permasalahannya. Negara yang berke-Tuhanan tidak menjamin warganya berke-Tuhanan. Apakah Pasal 29 ini juga mengisyaratkan adanya norma yang terkandung di dalamnya, agar negara bertanggung jawab dalam mengenalkan Tuhan kepada warganya? Untuk melihat hal ini lebih jelas, maka penulis akan mengupas Pasal 29 ini lebih mendalam.

Penjelasan Pasal 29 ayat (1) pada Undang-Undang Dasar awal kemerdekaan dituliskan bahwa, "Ayat ini menyatakan kepercayaan bangsa Indonesia terhadap

22 Undang-Undang Dasar Negara Republik Indonesia Tahun 1945. 
Tuhan Yang Maha Esa." 23 Maka perlu untuk ditinjau lebih dalam, apa sebenarnya yang dimaksud dengan menyatakan kepercayaan bangsa Indonesia terhadap Tuhan Yang Maha Esa? M. Yamin dalam buku "Pembahasan Undang-Undang Dasar Republik Indonesia" memuat dua penjelasan yang berkenaan dengan Pasal 29 ayat (1), sebagai berikut:

Pertama, pelaksanaan Pancasila dalam Konstitusi Proklamasi. Dalam Bab XI tentang Agama (Pasal 29) ditegaskan bahwa negara berdasarkan ke-Tuhanan Yang Maha Esa, sehingga jelaslah bahwa sila pertama dari pada ajaran Pancasila sebagai dasar negara tidak mungkin lain dari pada ke-Tuhanan Yang Maha Esa24. Kedua, tafsiran Undang-Undang Dasar 1945 No. 210 sampai No. 269. 250, tafsiran CXXXVI, ayat (1) ditambahkan oleh panitia dalam sidangnya tanggal 18 agustus tahun 1945. Tafsiran CXXXVII, berhubungan dengan Pasal 29 ayat (1). Maka istilah agama dalam Bab XI ini berarti agama yang ber-Tuhan Yang Esa. Jadi agama monoteis. Seperti ternyata menurut masing-masing kitab sucinya ${ }^{25}$.

Penjelasan M. Yamin pada bagian pertama, tentang negara berdasarkan keTuhanan Yang Maha Esa, hanyalah penegasan dari sila pertama Pancasila. Tujuan penegasan ini, agar di kemudian hari tidak ada perbedaan tafsir tentang yang di maksud dengan Tuhan Yang Maha Esa. Pasal 29 pada Undang-Undang Dasar dijadikan pengikat dari apa yang dimaksud dengan sila ke-Tuhanan Yang Maha Esa.

Penjelasan M. Yamin pada bagian kedua adalah, pertama, tentang penambahan ayat oleh panitia. Artinya ayat (1) ditambah setelah proklamasi kemerdekaan Indonesia. Kedua tentang penafsiran apa yang dimaksud dengan agama pada Bab XI. Agama yang dimaksud tidak lain adalah agama monoteisme, namun monoteis ini sesuai dengan tafsiran agama masing-masing yang tertera dalam kitab suci agama itu. Dalam hal ini, agama lain atau keyakinan lain, tidak boleh menginterfensi agama lain tentang apa yang dimaksud Tuhan Yang Maha Esa.

Pasal tentang keber-Tuhanan tidak mengalami perubahan pada amandemen Undang-Undang Dasar pada masa reformasi. Pasal ini tetap eksis dari pertama kali

${ }^{23}$ Muh. Yamin, Naskah Persiapan ..., Op. Cit., hlm. 44.

${ }^{24}$ Muhammad Yamin, Pembahasan Undang-Undang Dasar ..., Op. Cit., hlm. 462.

25 Ibid., hlm. 523. 
pengesahan sebagai Undang-Undang Dasar Negara Republik Indonesia hingga saat ini, kecuali pada masa pemberlakuan konstitusi RIS (Republik Indonesia Serikat). ${ }^{26}$ Pada masa pemberlakuan Konstisusi RIS pengakuan negara "Berdasar atas ke-Tuhanan Yang Maha Esa" hanya tercantum di dalam pembukaan saja.

Pernyataan lain yang menarik menurut peneliti adalah pernyataan Dahlan Ranuwihardjo, sebagai seorang ahli yang menyatakan:

“...Adanya ketentuan bahwa negara berdasar atas KeTuhanan Yang Maha Esa dalam Pasal 29 ayat (1), menunjukkan bahwa negara membebani diri untuk membimbing dan mengarahkan kehidupan religius rakyat kepada meyakini, meresapi dan menghayati adanya Tuhan Yang Maha Esa. Di dunia ini tidak banyak Undang-Undang Dasar yang mencantumkan bahwa negara berdasar KeTuhanan Yang Maha Esa. Pada hemat saya, sampai hari ini negara atau pemerintah kita, belum banyak berbuat untuk melakukan bimbingan terhadap rakyat yang masih percaya kepada yang lain selain Tuhan Yang Maha Esa..."27

Pernyataan ini baru peneliti dapati setelah tulisan ini telah $99 \%$ terselesaikan. Dari sekian banyak informasi yang peneliti kumpulkan, Dahlanlah satu-satunya yang memiliki cara pandang yang sama dengan peneliti, seperti tertera pada pernyataannya di atas. Perbedaannya dengan peneliti, bila dilihat dari pernyataannya di atas, adalah yang menjadi titik fokus permasalahan pembimbingan yang harus dilakukan oleh Negara. Menurut Dahlan yang perlu dibimbing adalah "Rakyat yang masih percaya kepada yang lain selain Tuhan Yang Maha Esa". Realitas saat ini, rakyat yang percaya terhadap Tuhan Yang Maha Esapun tetap mengalami permasalahan dengan pengetahuannya tentang Tuhan Yang Maha Esa. Hal ini bisa dilihat dari perbuatan-perbuatan rakyat yang mengklaim dirinya ber-Tuhan Yang Maha Esa.

Bila dilihat dari pasal atau ayat yang lainnya pada Undang-Undang Dasar, ada tiga Pasal yang menurut peneliti masih membuka kemungkinan yang akan mengantar seseorang untuk ber-Tuhan, sebagai berikut: Pertama, Pasal 29 ayat (2)

${ }^{26}$ Konstitusi Republik Indonesia Serikat (Konstitusi RIS).

27 Tim Penyusun Naskah Komprehensif Proses dan Hasil Perubahan UUD 1945, Naskah Komprehensif Perubahan Undang-Undang Dasar Negara Republik Indonesia Tabun 1945: Latar Belakang, Proses dan Hasil Pembahasan 1999-2002, Buku Satu, Cetakan Kedua, Edisi Revisi, Sekretariat Jenderal dan Kepaniteraan Mahkamah Konstitusi, Jakarta, 2010, hlm. 301. 
Undang-Undang Dasar menyebutkan bahwa "Negara menjamin kemerdekaan tiap-tiap penduduk untuk memeluk agamanya masing-masing dan untuk beribadat menurut agamanya dan kepercayaan itu." Dari bunyi pasal ini maka sangat jelas bahwa negara dalam hal ini hanyalah memberikan jaminan seseorang untuk beragama. Negara tidak memperdulikan rakyatnya apakah telah mengenal Tuhannya sehingga rakyat tersebut sadar untuk memilih agama mana atau kepercayaan apa yang akan dipeluknya.

Kedua, Pasal 28 E ayat (1) Undang-Undang Dasar menyebutkan bahwa "Setiap orang bebas memeluk agama dan beribadat menurut agamanya, memilih pendidikan dan pengajaran, memilih pekerjaan, memilih kewarganegaraan, memilih tempat tinggal di wilayah negara dan meninggalkannya dan berhak kembali." Pasal ini tidaklah berbeda secara subtansi dengan Pasal 29 ayat (2) Undang-Undang Dasar. Pasal ini hanya menjelaskan hak seseorang untuk memilih dan/atau tidak memilih untuk beragama. Pasal ini tidak menjelaskan tentang bagaimana ber-Tuhan. Ayat (2) "Setiap orang berhak atas kebebasan meyakini kepercayaan, menyatakan fikiran dan sikap sesuai dengan hati nuraninya."

Ayat (2) hanya menjelaskan hak dari seseorang untuk berkeyakinan bukan bagaimana cara berkeyakinan. Pasal 28E tidak ada penjelasan tentang bagaimana ber-Tuhan melainkan hanya norma yang menjamin tentang hak untuk beragama dan berkeyakinan seorang manusia. Permasalahan bagaimana seseorang berkeyakinan tidak dijelaskan, bahwa negara berperan dalam hal ini. Artinya negara kembali berlepas tangan dalam tanggung jawabnya untuk memberikan pencerdasan tentang Tuhan yang sebenarnya, sehingga seseorang bisa bersifat seperti sifat Tuhan.

Ketiga, Pasal 31 ayat (1) Undang-Undang Dasar "Setiap warga negara berhak mendapat pendidikan." Ayat ini yang menyatakan tanggung jawab negara tentang anak bangsa untuk mendapatkan pengetahuan. Pendidikan adalah suatu alat untuk mencerdaskan kehidupan bangsa. Permasalahan yang peneliti sampaikan di paragraf sebelumnya adalah permasalahan pengetahuan yakni pengetahuan tentang Tuhan Yang Maha Esa. Pendidikan yang diselenggarakan oleh negara seharusnya memuat materi tentang pengetahuan atau pengenalan terhadap Tuhan Yang Maha Esa. Ayat (2) "Setiap warga negara wajib mengikuti pendidikan dasar 
dan pemerintah wajib membiayainya." Negara menekankan kepada warga negara untuk mewajibkan dirinya mendapatkan pengetahuan dasar. Upaya pencerdasan ini, keseriusan pemerintah terlihat pada ayat (4) "Negara memprioritaskan anggaran pendidikan sekurang-kurangnya dua puluh persen dari anggaran pendapatan dan belanja negara serta dari anggaran pendapatan dan belanja daerah untuk memenuhi kebutuhan penyelenggaraan pendidikan nasional." Pertanyaan peneliti, apakah anggaran yang dianggarkan oleh pemerintah telah dilaksanakan secara maksimal?

Permasalahan lainnya apakah pada pendidikan dasar ada pengenalan tentang Tuhan Yang Maha Esa? Pengenalan terhadap Tuhan Yang Maha Esa bukanlah pengetahuan sederhana atau mudah untuk dimengerti. Pengetahuan tentang Tuhan Yang Maha Esa adalah kajian filosofis (filsafat). Pertanyaannya apakah sistem pendidikan di Indonesia telah mengajarkan berfikir filosis di tingkat dasar?

Berfikir secara filosofis baru didapatkan oleh seorang pelajar pada pendidikan strata 3. Pendidikan strata satu biasanya yang diajarkan bukan bagaimana berfilsafat melainkan mengenal aliran dan sejarah filsafat, jadi sangat kecil kemungkinan seseorang untuk bisa berfikir filosofis. Di strata dua, seorang pelajar barulah sedikit lebih ditekankan untuk berfikir filosofis yang sifatnya praktis, padahal pengetahuan filosofis memerlukan pengetahuan teoritis yang kuat.

Belum lagi untuk sampai kepada pendidikan di jenjang tinggi ini harus mengeluarkan biaya yang sangat besar. Negara memang menyediakan beasiswa namun sangat terbatas. Sebagian besar para pemuda dan pemudi Indonesia tidak memiliki kecakapan secara administrasi untuk mendapatkan beasiswa tersebut. Maka negara kembali berlepas tangan terhadap pengetahuan rakyatnya terhadap Tuhan Yang Maha Esa.

Selayaknya terlebih dahulu peneliti akan melihat sistem pendidikan yang dimaksud. Pada ayat (3) "Pemerintah mengusahakan dan menyelenggarakan satu sistem pendidikan nasional, yang meningkatkan keimanan dan ketakwaan serta akhlak mulia dalam rangka mencerdaskan kehidupan bangsa, yang diatur dengan 
undang-undang." Untuk mengetahui muatan pendidikan seperti apa yang akan diusahakan dan diselenggarakan oleh pemerintah, maka hal yang perlu untuk ditinjau adalah muatan kurikulum yang telah diatur dalam undang-undang. Dalam Undang-Undang No. 20 Tahun 2003 tentang Sistem Pendidikan Nasional (selanjutnya disebut UU Sisdiknas) disebutkan bahwa:

Pasal 36 ayat (3) "Kurikulum disusun sesuai dengan jenjang pendidikan dalam kerangka Negara Kesatuan Republik Indonesia dengan memperhatikan: a. Peningkatan iman dan takwa, b. Peningkatan akhlak mulia, c. Peningkatan potensi, kecerdasan, dan minat peserta didik, d. Keragaman potensi daerah dan lingkungan, e. Tuntutan pembangunan daerah dan nasional, f. Tuntutan dunia kerja, g. Perkembangan ilmu pengetahuan, teknologi, dan seni, h. Agama, i. Dinamika perkembangan global, dan j. Persatuan nasional dan nilai-nilai kebangsaan."

Pasal 37 ayat (1) Kurikulum pendidikan dasar dan menengah wajib memuat: a. Pendidikan agama, b. Pendidikan kewarganegaraan, c. Bahasa, d. Matematika, e. Ilmu pengetahuan alam, f. Ilmu pengetahuan sosial, g. Seni dan budaya, h. Pendidikan jasmani dan olahraga, i. Keterampilan/kejuruan, dan j. Muatan lokal.

Ayat (2) Kurikulum pendidikan tinggi wajib memuat: a. Pendidikan agama, b. Pendidikan kewarganegaraan, dan c. Bahasa."

Muatan kurikulum di atas menunjukkan bahwa pengenalan terhadap Tuhan Yang Maha Esa dimasukkan pada pendidikan agama. Pasal 31 ayat (5) UndangUndang Dasar disebutkan "Pemerintah memajukan ilmu pengetahuan dan teknologi dengan menjunjung tinggi nilai-nilai agama dan persatuan bangsa untuk kemajuan peradaban serta kesejahteraan umat manusia." Tanggung jawab yang besar ini apakah efektif bila diberikan kepada pendidikan agama? Pendidikan formal dari sekolah dasar hingga pendidikan tinggi, pendidikan agama tidak banyak memberikan penjelasan tentang Tuhan Yang Maha Esa secara filosofis.

Pengetahuan tentang Tuhan melalui metode agama akan menghasilkan kesimpulan yang berbeda terhadap pandangan dunia seseorang dengan pengetahuan Tuhan yang diperoleh melalui metode filsafat. Pengetahuan yang diperoleh melalui agama lebih bersifat doktrin, sedangkan pengetahuan yang diperoleh dari metode filsafat lebih bersifat teoritis. Tindakan yang dihasilkan dari dua metode di atas tentunya juga menimbulkan perbedaan. Pengetahuan tentang Tuhan diperoleh dari doktrin agama lebih bersifat tertutup, sedangkan yang 
diperoleh melalui pengetahuan teoritis dengan penalaran akal akan bersifat lebih terbuka dan tahan uji atau siap untuk diperdebatkan.

Konsekuensi seseorang memperoleh pengetahuan Tuhan melalui doktrin agama membuka kemungkinan besar seseorang akan berbuat anarkis. Orangorang yang bertindak radikal seperti teroris yang berkedok agama biasanya terlebih dahulu disirami dengan ayat-ayat suci agama yang bersifat doktrin. Pengetahuan ini akan membuat orang yang melakukan tindakan radikal, misalnya saja bom bunuh diri. Orang tersebut meyakini bahwa perbuatannya adalah perbuatan yang benar dan berjuang di jalan yang dikehendaki oleh Tuhan atau yang disebut dengan jihat.

Terlihat berbeda bila seseorang yang memperoleh pengetahuan tentang Tuhan melalui pengetahuan teoritis melalui metode filsafat. Orang yang menggunakan akalnya untuk melakukan penalaran secara mendalam akan lebih waspada dalam tindakannya. Misalnya jika ada orang yang melakukan doktrin seperti di atas, maka orang tersebut akan menimbulkan banyak pertanyaan didalam dirinya. Misalnya pertanyaan apakah benar Tuhan berkehendak demikian? Apakah Tuhan itu kejam atau penuh dengan kasih sayang?

Pertanyaan-pertanyaan tersebut akan dijawabnya melalui proses berfikir yang mendalam atau perenungan. Tuhan terkenal dengan sifat yang penuh dengan kasih dan sayang. Tuhan tidak pernah memaksa ciptaan-Nya untuk berbuat sesuatu artinya Tuhan memberikan kebebasan kepada ciptaan-Nya. Kebebasan yang diberikan oleh Tuhan kepada ciptaan-Nya di barengi dengan petunjuk-Nya melalui alam (akal) atau melalui para utusan-Nya.

Bom bunuh diri adalah tindakan pemaksaan terhadap sesuatu. Karena orang lain tidak mau mengikuti seperti apa yang diinginkan oleh orang tertentu sehingga orang tersebut melakukan pemaksaan dengan cara melakukan teror. Tentu perbuatan teror tidaklah mencerminkan sifat kasih dan sayang dan perbuatan itu tidak bisa disandarkan kepada Tuhan Yang Maha Esa. Teror dan kasih sayang adalah sifat yang memiliki kontradiksi dan tidak akan pernah bersatu.

Sangat jelas perbedaan antara pengetahuan yang diperoleh melalui doktrin dan pengetahuan teoritis. Maka pendidikan agama yang diterima di sekolah yang 
pada umumnya lebih bersifat pada pengetahuan doktrin, tidak bisa mengantarkan seseorang kepada pengenalan terhadap Tuhan Yang Maha Esa secara mendalam. Para koruptor bukan anak jalanan yang tidak mengenyam pendidikan melainkan mereka yang menjalani pendidikan dari dasar hingga tinggi. Sekali lagi menurut peneliti negara kembali berlepas tangan terhadap hal yang paling mendasar ini.

Undang-Undang Dasar bila dilihat dari politik hukum dibentuknya maka jelas bahwa negara memiliki kewajiban untuk mencerdaskan kehidupan bangsa yang berdasarkan kepada keadilan sosial. Undang-undang turunannya yakni UU Sisdiknas selain menekan kembali politik hukum dari Undang-Undang Dasar menyatakan "Meningkatkan keimanan dan ketakwaan kepada Tuhan Yang Maha Esa serta akhlak mulia dalam bangsa." Dan "Menjamin pemerataan kesempatan pendidikan, peningkatan mutu serta relevansi dan efisiensi manajemen pendidikan untuk menghadapi tantangan sesuai dengan tuntutan perubahan kehidupan lokal, nasional, dan global sehingga perlu dilakukan pembaharuan pendidikan secara terencana, terarah, dan berkesinambungan." Tujuan dibentuknya undang-undang turunan untuk mencerdaskan kehidupan berbangsa telah mencerminkan niat baik, namun niat baik yang tidak terimplementasikan tidaklah berarti di dalam kehidupan berbangsa.

Negara tidaklah bertindak berdasarkan keadilan sosial, karena negara tidak bertanggung jawab dalam memberikan pencerdasan tentang pengetahuan Tuhan Yang Maha Esa. Dasar negara tidak ubahnya hanyalah sekedar pajangan yang tertulis dilembaran kertas dan ditempelkan di dinding-dinding sekolah. Bagaimana mungkin seorang petani akan berhasil dalam panen apabila hanya diberikan bibit tanpa diberikan penjelasan bagaimana cara menggunakan bibit yang diberikan. Gagal panen telah di depan mata karena kemungkinan besar petani akan melakukan banyak tindakan yang seharusnya tidak dilakukannya karena keterbatasan pengetahuan.

Tindakan negara tentang dasar negara tidak ubahnya seperti memberikan bibit kepada petani tanpa ada penjelasan tentang bibit tersebut. Bibit yang unggul tidak memastikan hasil panen yang baik begitu juga dasar negara yang baik tidak menjamin warga negara yang baik. Seharusnya negara memberikan penjelasan tentang dasar negara yang telah disepakati agar tidak terjadi multi tafsir apalagi 
salah tafsir. Bagaimana mungkin Pancasila akan menjadi pedoman hidup dalam bermasyarakat bila individu-individu yang ada di dalam masyarakatnya tidak memiliki pengetahuan tentang Tuhan Yang Maha Esa.

Negara tidak meletakkan sesuatu sebagaimana mestinya. Negara tidak meletakkan sesuatu pada tempatnya dikarenakan negara tidak menyediakan tempat dari sesuatu itu. Dalam pandangan hukum alam jelaslah bahwa keadilan harus di utamakan. Hukum dibuat bukan hanya sekedar aturan yang tertulis atau bukanlah untuk hukum semata, tetapi hukum dibuat adalah alat untuk mencapai keadilan. Keadilan tidaklah lain merupakan fitrah atau kebutuhan yang bersumber dari dalam diri manusia untuk mencapai kebahagiaan.

Di lihat dari sudut pandang hukum alam, maka seharusnya aturan dibuat tidak boleh bertentangan dengan hak alamiah dari seseorang. Pancasila sebagai dasar negara terutama Sila Ke-Tuhanan Yang Maha Esa, jelas merupakan hak alamiah dari setiap manusia. Selayaknya negara memprioritaskan permasalahan ini untuk ditanggulangi.

\section{Penutup}

Berdasarkan uraian di atas, dapat disimpulkan bahwa, pertama, Pasal 29 Undang-Undang Dasar Negara Republik Indonesia Tahun 1945 tidak relevan lagi dengan Pancasila, sila ke-Tuhanan Yang Maha Esa. Tidak relevan ini bukan berarti tidak berhubungan sama sekali atau bertentangan. Tidak relevan yang dimaksud, bahwa Pasal 29 Undang-Undang Dasar Negara Republik Indonesia Tahun 1945 tidak berhubungan dengan warga negara yang ber-Tuhan, namun lebih kepada negara yang ber-Tuhan. Permasalahan krisis keber-Tuhanan bukan berarti negara tidak ber-Tuhan, namun lebih kepada warga negara yang melakukan perbuatan "Tidak ber-Tuhan" atau menjadikan dirinya "Tuhan".

Kedua, permasalahan krisis keber-Tuhanan yang marak saat ini tidak ada diatur dalam peraturan perundang-undangan. Undang-Undang Dasar sebagai norma tertinggi tidak memberikan pengaturan bagaimana agar warga negara bisa ber-Tuhan dengan benar, namun lebih kepada sekedar pengakuan akan adanya Tuhan saja. Hal ini tertuang di dalam Undang-Undang Dasar, Pasal 29 ayat (1). 
Pengakuan negara terhadap adanya Tuhan tidak menjamin warga negara berTuhan dengan benar.

Perlu dilakukan amandemen kelima Undang-Undang Dasar Negara Republik Indonesia Tahun 1945 untuk memasukkan Pasal/ayat khusus tentang bagaimana orang bisa ber-Tuhan. Adapun Pasal/ayat yang perlu untuk tambah yakni pertama,perlu adanya penambahan Pasal/ayat yang mengatur bagaimana cara warga negara mengenal Tuhan Yang Maha Esa secara filosofis dengan benar. Kedua, perlu adanya penambahan Pasal/ayat yang mengatur suatu lembaga yang khusus melakukan pencerahan tentang Tuhan Yang Maha Esa. Ketiga, perlu adanya penambahan Pasal/ayat yang mengatur orang yang layak atau kriteria yang berhak menjadi tim pengajar yang akan mengenalkan Tuhan Yang Maha Esa.

\section{Daftar Pustaka}

\section{Buku}

Divisi kampanye ABTI, Asa Itu (Masih) Ada-orang muda dalam antologi esai keberagaman, Cetakan Pertama, ANBTI, Jakarta Selatan, 2010.

Hatta, Muhammad, Menuju Negara Hukum, Cetakan Kedua, Idayu Press, Jakarta, 1977.

Pengertian Pancasila, Idayu Press, Jakarta, 1977.

Maarif, Ahmad Syafii, Islam dan Masalah Kenegaraan, Cetakan Ketiga, LP3ES, Jakarta, 1996.

Sukarno, Pancasila, Cetakan Pertama, Idayu Press, Jakarta, 1984.

Thaib, Dahlan et. al., Teori dan Hukum Konstitusi, Cetakan keenam, Edisi Pertama, Rajawali Pers, Jakarta, 2006.

Tim Penyusun Naskah Komprehensif Proses dan Hasil Perubahan UUD 1945, Naskah Komprehensif Perubahan Undang-Undang Dasar Negara Republik Indonesia Tahun 1945: Latar Belakang, Proses dan Hasil Pembahasan 1999-2002, Buku Satu, Cetakan Kedua, Edisi Revisi, Sekretariat Jenderal dan Kepaniteraan Mahkamah Konstitusi, Jakarta, 2010.

Wikasari, Ika, Amandemen UUD 1945, Cetakan Pertama, Buku Pintar, Yogyakarta, 2013.

Yamin, Muh., Naskah Persiapan Undang-Undang Dasar 1945, Cetakan Kedua, Jilid Pertama, 1971.

, Pembahasan Undang-Undang Dasar Republik Indonesia, Djakarta, Jajasan Prapantja, 1960. 


\section{Peraturan Perundang-undangan}

Undang-Undang Dasar Negara Republik Indonesia Tahun 1945.

Konstitusi Republik Indonesia Serikat (KONSTITUSI RIS).

Undang-Undang Negara Republik Indonesia Nomor 20 Tahun 2003 tentang Sistem Pendidikan Nasional (Tambahan Lembaran Negara Republik Indonesia Nomor 4301)

Keputusan Menteri Lingkungan Hidup Nomor 14 Tahun 2016 tentang Reklamasi Dan Revitalisasi Pantai Utara

\section{Data Elektronik}

http://www.bps.go.id/Brs/view/id/1158Kemiskinan diakses pada tanggal 10 Juli 2017.

http:/ / m.merdeka.com/peristiwa / pakar-indonesia-masih-rawan-pangan.html diakses pada tanggal 26 Juni 2017.

http:/ / bisniskeuangan.kompas.com/read/2015/12/20/121300726/5.masalah.ek onomi.Indonesia.yang.tidak.boleh.terulang.di.tahun2016 diakses pada tanggal 26 Juni 2017.

http:/ / m.okezone.com/read/2015/09/16/320/1215049/rizal-ramli-ungkapmasalah-maritim-di-indonesia diakses pada tanggal 25 Juni 2017.

http:/ / m.liputan6.com/news/read/2371659/ini-akar-masalah-freport-versimantan-dirjen-minerba-esdm diakses pada tanggal 24 Juni 2017.

http:/ / nasional.sindonews.com/read/945259/144/masalah-pendidikan-yangtak-pernah-tuntas-142018784 diakses pada tanggal 24 Juni 2017.

http:/ / kbbi.web.id/relevansi diakses pada tanggal 24 Juni 2017. 